\title{
Vancomycin susceptibility profiles of Staphylococcus spp. isolates from domestic and wild animals
}

\author{
Janaina Marcela Assunção Rosa Moreira ${ }^{1 *}$ (D) Isabela Godoy Menezes ${ }^{1}(\mathbb{D}$ \\ Indira Silva Rezende Luna ${ }^{1}$ (D) Beatriz Silva Nogueira ${ }^{1}$ iD \\ Alessandra Tammy Hayakawa Ito de Sousa ${ }^{1}$ (D) Stéfhano Luís Cândido ${ }^{1}$ (iD \\ Valeria Dutra ${ }^{1}$ (D) Luciano Nakazato ${ }^{1}$ (iD
}

${ }^{1}$ Laboratório de Microbiologia Veterinária e Biologia Molecular, Universidade Federal de Mato Grosso (UFMT), 78060-900, Cuiabá, MT, Brasil. E-mail: janarosavet@gmail.com. .Corresponding author.

ABSTRACT: Staphylococcus spp. are bacteria involved in human and animal infections. They are resistant to antimicrobials and have become a major public health concern. In recent years, there has been a significant increase in methicillin-resistant Staphylococcus strains and vancomycin is the drug of choice for the treatment of such isolates. However, the minimum inhibitory concentration (MIC) of vancomycin necessary to combat this microorganism has been showing an increase. The aim of the present study was to determine the susceptibility profile of the Staphylococcus spp. of domestic and wild animals to vancomycin, using the microdilution in broth and E-test ${ }^{\circledR}$ techniques, as well as comparing the results of both tests. Of the 50 isolates tested, 47 (94\%) were sensitive to vancomycin in the microdilution and 43 (86\%) were sensitive to vancomycin in the E-test ${ }^{\mathbb{E}}$. Seven (14\%) isolates had an intermediate result showing a risk to public health since the detection of these isolates may precede the occurrence of isolates resistant to vancomycin. In addition, the mecA gene was detected in $78 \%$ of the tested samples. Six of the seven isolates with intermediate resistance to vancomycin were carriers of the mecA gene, showing that these isolates had a potential risk of becoming resistant. Thus, control measures must be taken to prevent the spread of these isolates with intermediate resistance and preserve the effectiveness of this antimicrobial for the treatment of infections caused by multiresistant Staphylococcus spp.

Key words: multiresistant bacteria, minimum inhibitory concentration, Staphylococcus spp., intermediate resistance to vancomycin; mecA.

Perfil de suscetibilidade à Vancomicina de isolados de Staphylococcus spp.

de animais domésticos e silvestres

RESUMO: Staphylococcus spp. são bactérias envolvidas em infecções de humanos e animais, resistentes a antimicrobianos e tem se tornado uma grande preocupação em saúde pública. Nos últimos anos houve um aumento significativo de Staphylococcus resistentes à meticilina e a vancomicina é a droga de escolha para o tratamento desses isolados, porém vem apresentando elevação nos valores de Concentração Inibitória Minima (CIM) necessários para combater este microrganismo. O objetivo do presente trabalho foi determinar o perfil de suscetibilidade à vancomicina para isolados de Staphylococcus spp. de animais domésticos e silvestres pelas técnicas de Microdiluição em caldo e E-test ${ }^{\mathbb{Q}}$, bem como comparar os resultados de ambos os testes. Dos 50 isolados testados 47 (94\%) foram sensíveis à vancomicina na Microdiluição e $43(86 \%)$ foram sensiveis à vancomicina no E-test ${ }^{\circledR}$. Sete (14\%) isolados tiveram resultado intermediário demonstrando um risco à saúde pública visto que a detecção destes isolados pode preceder a ocorrência de isolados resistentes à vancomicina. Ademais o gene mecA foi detectado em $78 \%$ das amostras testadas, sendo que dos sete isolados com resistência intermediária à vancomicina, seis eram portadores do gene mecA, evidenciando que esses isolados possuem potencial risco de se tornarem resistentes. Dessa forma medidas de controle devem ser tomadas para evitar a propagação destes isolados com resistência intermediária e preservar a eficácia deste antimicrobiano para o tratamento de infecções causadas por Staphylococcus multirresitentes.

Palavras-chave: bactérias multirresistentes, concentração inibitória mínima, Staphylococcus spp., resistência intermediária à vancomicina, mecA.

\section{INTRODUCTION}

Bacterial resistance to antibiotics is a threat to public health and drug-resistant bacteria could cause 10 million deaths each year until 2050 . This problem has become a concern in veterinary medicine; the concept of "One Health", where human health, animal health and the environment are fully integrated, is extremely important when considering bacterial resistance to antimicrobials (ONU, 2019).

The potential risk of transmitting antimicrobial resistant isolates from animals to 
humans and vice-versa is associated with close contact between animals and their guardians and the inappropriate use of antimicrobials, since drugs used in the treatment of humans are administered in animals as growth enhancers and in the treatment and prophylaxis of infections (LOUREIRO et al., 2016; CERIC et al., 2019).

Bacteria of the genus Staphylococcus are considered opportunistic pathogens in several diseases of humans and animals, with Staphylococcus aureus being the species most commonly involved in human infections, followed by $S$. pseudintermedius in dogs and cats (SAPUTRA et al., 2017). The emergence of Staphylococcus spp. resistant to antimicrobials, especially methicillin, has been of concern in recent years, and effective treatment options in animals are decreasing (PAPICH, 2013).

Vancomycin is an antibiotic of the glycopeptide class, whose mechanism of action is to prevent the synthesis of the cell wall of microorganisms. In recent decades, it has been an effective solution in the treatment of infections caused by pathogens resistant to methicillin, particularly Staphylococcus spp. (MCGUINNESS et al., 2017). Among the glycopeptides, vancomycin is the only one used in veterinary medicine. Despite being a widely used drug in humans, its use in animals is still uncommon due to its toxicity, need for intravenous administration by slow infusion and its high cost. However, gradual increases in its minimum inhibitory concentration (MIC) values have been reported (PAPICH, 2013).

Staphylococcus spp. with reduced sensitivity to vancomycin has been reported in the last 20 years and isolates with intermediate resistance and hetero resistance are more frequent than isolates with full resistance (HUANG et al., 2016). The first strain of methicillin-resistant Staphylococcus aureus (MRSA) with intermediate resistance to vancomycin was reported by HIRAMATSU et al. (1997) in Japan, isolated from a child being treated with vancomycin due to a surgical infection. Although, Staphylococcus with reduced susceptibility to vancomycin has already been reported in animals (MORENO et al., 2016), there is still little research on the frequency of these isolates in animals (WIJESEKARA et al., 2017).

Thus, this research aimed to determine and compare the vancomycin MIC against isolates of Staphylococcus spp. from injuries to domestic and wild animals, by broth microdilution and E-test $^{\circledR}$ techniques.

\section{MATERIALS AND METHODS}

\section{Isolates}

The tested isolates of Staphylococcus spp. came from a previous study of the susceptibility profile to antimicrobials carried out by GODOY et al. (2016). One hundred isolates of Staphylococcus spp. underwent a vancomycin susceptibility test $(30 \mu \mathrm{g}$, Cefar Diagnóstica Ltda), using the Mueller-Hinton agar diffusion disc method, according to BAUER et al. (1966), with an inhibition zone $\leq 14 \mathrm{~mm}$. The isolates with a halo equal to or less than $14 \mathrm{~mm}$ were selected to determine the MIC of vancomycin, either by the broth microdilution method or by E-test ${ }^{\mathbb{R}}$.

There were 50 isolates of Staphylococcus spp. altogether, 42 of which were isolated from dogs, 4 from felines, 1 from bovine, 1 from equine, 1 from Procyon cancrivorus (Raccoon), 1 from Nasua nasua (coati) and 1 from Lycalopex vetulus (fox of the field). All were isolated from clinical cases. These data are shown in table 1.

The isolates were previously identified as species of Staphylococcus by GODOY et al. (2016) and $92 \%$ were coagulase positive, with $64 \%(32 / 50)$ being $S$. pseudintermedius and $20 \%$ (10/50) being $S$. schleiferi. S. aureus and $S$. delphini each represented only $4 \%(2 / 50)$ of the total of isolates. Coagulase negative Staphylococcus (S. sciuri, S. simulans and S. felis) represented $8 \%$ of the total samples $(4 / 50)$.

\section{Minimum inhibitory concentration}

The broth microdilution technique is considered the gold standard technique and was performed according to CLSI (2013). Ten serial dilutions of vancomycin (Sigma-Aldrich), ranging from $64-0.125 \mu \mathrm{g} / \mathrm{mL}$, were tested in MuellerHinton broth. After inoculation and standardization of the bacterial suspension to 0.5 on the McFarland scale followed by incubation at $37{ }^{\circ} \mathrm{C}$ for $24 \mathrm{~h}$, the MIC was determined to be the lowest concentration in which there was no visible growth. The tests were performed in duplicate.

The E-test ${ }^{\circledR}$ (Biomerieux) was performed according to the manufacturer's instructions. After inoculation of the bacterial suspension (diluted to 0.5 on the McFarland scale) on Mueller-Hinton agar, the strip was deposited and incubated at 37 ${ }^{\circ} \mathrm{C}$ for $24 \mathrm{~h}$. The reading was performed at the point where the ellipse intercepted the E-test ${ }^{\circledR}$ strip. Enterococcus faecalis ATCC 29212 (vancomycinsusceptible) and Enterococcus faecalis ATCC 51299 (vancomycin-resistant) were used as quality control of the tests. 
Table 1 - Frequency of Staphylococcus species identified in different animal hosts.

\begin{tabular}{|c|c|c|c|c|c|c|}
\hline Species & Injury site & Canine & Feline & Bovine & Equine & Wild \\
\hline \multirow{2}{*}{ S. aureus } & Feces & -- & -- & 1 & -- & -- \\
\hline & injury swab & -- & -- & -- & 1 & -- \\
\hline \multirow{2}{*}{ S. delphini } & Otological swab & 1 & -- & -- & -- & -- \\
\hline & Fur & 1 & -- & -- & -- & -- \\
\hline \multirow{2}{*}{ S. felis } & Otological swab & 1 & -- & -- & -- & -- \\
\hline & Urine & -- & 1 & -- & -- & -- \\
\hline \multirow{6}{*}{ S. pseudintermedius } & Liquor & 1 & -- & -- & -- & -- \\
\hline & Otological swab & 16 & 1 & -- & -- & $1 \mathrm{c}$ \\
\hline & Fur & 6 & -- & -- & -- & -- \\
\hline & Oral swab & -- & -- & -- & -- & $1^{\mathrm{B}}$ \\
\hline & Eye swab & 2 & -- & -- & -- & -- \\
\hline & Urine & 3 & 1 & -- & -- & -- \\
\hline \multirow{2}{*}{ S. schleiferi } & Otological swab & 9 & -- & -- & -- & -- \\
\hline & Lung & 1 & -- & -- & -- & -- \\
\hline S. sciuri & Eye swab & -- & -- & -- & -- & $1^{\mathrm{A}}$ \\
\hline S. simulans & Nail & -- & 1 & -- & -- & -- \\
\hline Total & & & & & & 50 \\
\hline
\end{tabular}

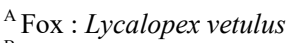

${ }^{\mathrm{B}}$ Raccoon: Procyon cancrivorus

${ }^{\mathrm{C}}$ Coati: Nasua nasua.

\section{Interpretation of results}

Results were interpreted according to the Clinical and Laboratory Standards Institute (CLSI) document VET01-S2, where isolates with $\mathrm{MIC} \leq 4$ $\mu \mathrm{g} / \mathrm{mL}$ were considered sensitive, isolates with MIC between $8-16 \mu \mathrm{g} / \mathrm{mL}$ were considered intermediate and isolates with $\mathrm{MIC} \geq 32 \mu \mathrm{g} / \mathrm{mL}$ were resistant (CLSI, 2013).

\section{Statistical analysis}

Statistical analysis of the data was performed using a Chi-squared test with a significance level of $\mathrm{P}<0.05$. Correlation and the degree of agreement of the tests were measured by Kappa using R (R-3.6.1).

\section{Detection of the mecA gene}

Determination of methicillin resistance was also performed, by detecting the presence of the mecA gene through PCR, with specific primers $m e c A 1$ 5'- CCT AGT AAA GCT CCG GAA -3 and mecA2 5'-CTA GTC CAT TCG GTC CA-3'. The primers amplify a $331 \mathrm{bp}$ fragment of the $m e c A$ gene, according to the protocol described by $\mathrm{CHOI}$ et al. (2003). The amplification products were analysed by electrophoresis on $1.5 \%$ agarose gel, stained with Gel Red TM $^{\text {TBiotium }}{ }^{\circledR}$ ) and observed in a ChemiDoc TM
XRS photo-documenter using the ImageLab software, with a 100 bp molecular mass marker (Ludwig).

\section{RESULTS AND DISCUSSION}

Of the 50 isolates tested for the determination of the MIC of vancomycin, 94 $\%(47 / 50)$ and $86 \%(43 / 50)$ were sensitive to vancomycin by microdilution in broth and E-test ${ }^{\circledR}$ respectively. Fourteen percent (7/50) of the isolates showed intermediate resistance to vancomycin.

Several methodologies are used to determine the susceptibility profile to antimicrobials; however, for vancomycin it is recommended to determine the MIC by dilution methods (broth microdilution, tube macrodilution, water dilution) or, alternatively, by using E-test ${ }^{\circledR}$ tapes or automated systems (CLSI, 2013; CAMPANA et al., 2011).

The disk diffusion technique was used only as a screening method for Staphylococcus resistance to vancomycin, since it is not able to predict the MIC and is not recommended by CLSI (2013) due to the low accuracy in identifying isolates with intermediate or full resistance, and even isolates heteroresistant to this glycopeptide (CAMPANA et al., 2011). 
It was reported that the vancomycin MICs varied from $1-8 \mu \mathrm{g} / \mathrm{mL}$ by microdilution in broth and from $1-16 \mu \mathrm{g} / \mathrm{mL}$ by E-test ${ }^{\circledR}$. The majority of the MICs determined by the E-test ${ }^{\circledR}$ were $4 \mu \mathrm{g} / \mathrm{mL}$ (33 isolates, $66 \%$ ), while the majority of the MICs determined by microdilution were $2 \mu \mathrm{g} / \mathrm{mL}$ (33 isolates, $66 \%$ ). In figure 1 , it is possible to see the distribution of MIC values for vancomycin obtained by the two tests. Results of the Staphylococcus spp. together, the MIC values for vancomycin by broth microdilution and E-test ${ }^{\circledR}$ can be seen in table 2 .

PAIVA et al. (2010) reported MICs ranging from $0.25-2 \mu \mathrm{g} / \mathrm{mL}$ by microdilution and between $0.38-3 \mu \mathrm{g} / \mathrm{mL}$ by E-test ${ }^{\circledR}$ in a study with 130 coagulase-negative Staphylococcus spp. isolated from humans. SWENSSON et al. (2009), in a study with $129 \mathrm{~S}$. aureus isolates, obtained MICs ranging from $0.5-8 \mu \mathrm{g} / \mathrm{mL}$ in both tests. The data demonstrated that the isolates tested in the present study had MICs greater than those reported by PAIVA et al. (2010) and similar to those reported by SWENSSON et al. (2009), evidencing the increase in vancomycin MICs needed to fight the microorganism.

Seven $(14 \%)$ of the isolates had intermediate resistance, three detected by the two tests and four detected only by the E-test ${ }^{\circledR}$. Of these seven: five were $S$. pseudintermedius isolates from dogs, whose isolation sites were otological swab, fur and ocular swab; one was $S$. aureus isolated from bovine feces; and one was $S$. schleiferi isolated from a dog ear. The detection of these isolates is extremely important to establish a monitoring system for antimicrobial resistance with a "One Health" approach (CERIC et al., 2019) and represents a challenge for the treatment of infections caused by Staphylococcus spp. in humans and animals around the world as there is a need to avoid therapeutic failure (HUANG et al., 2016).

Staphylococcus spp. with methicillin resistance are considered multidrug-resistant (MDR) since they are resistant to all $\beta$-lactams and; therefore, are considered a challenge for clinical practice (CERIC et al., 2019). The mecA gene was detected in $78 \%(39 / 50)$ of the samples tested in this study and six of the seven isolates with intermediate resistance to vancomycin were carriers of the mecA gene. This fact that may explain the detection of elevated vancomycin MIC values that resulted in isolates with intermediate resistance to glycopeptide, since infections by isolates resistant to methicillin

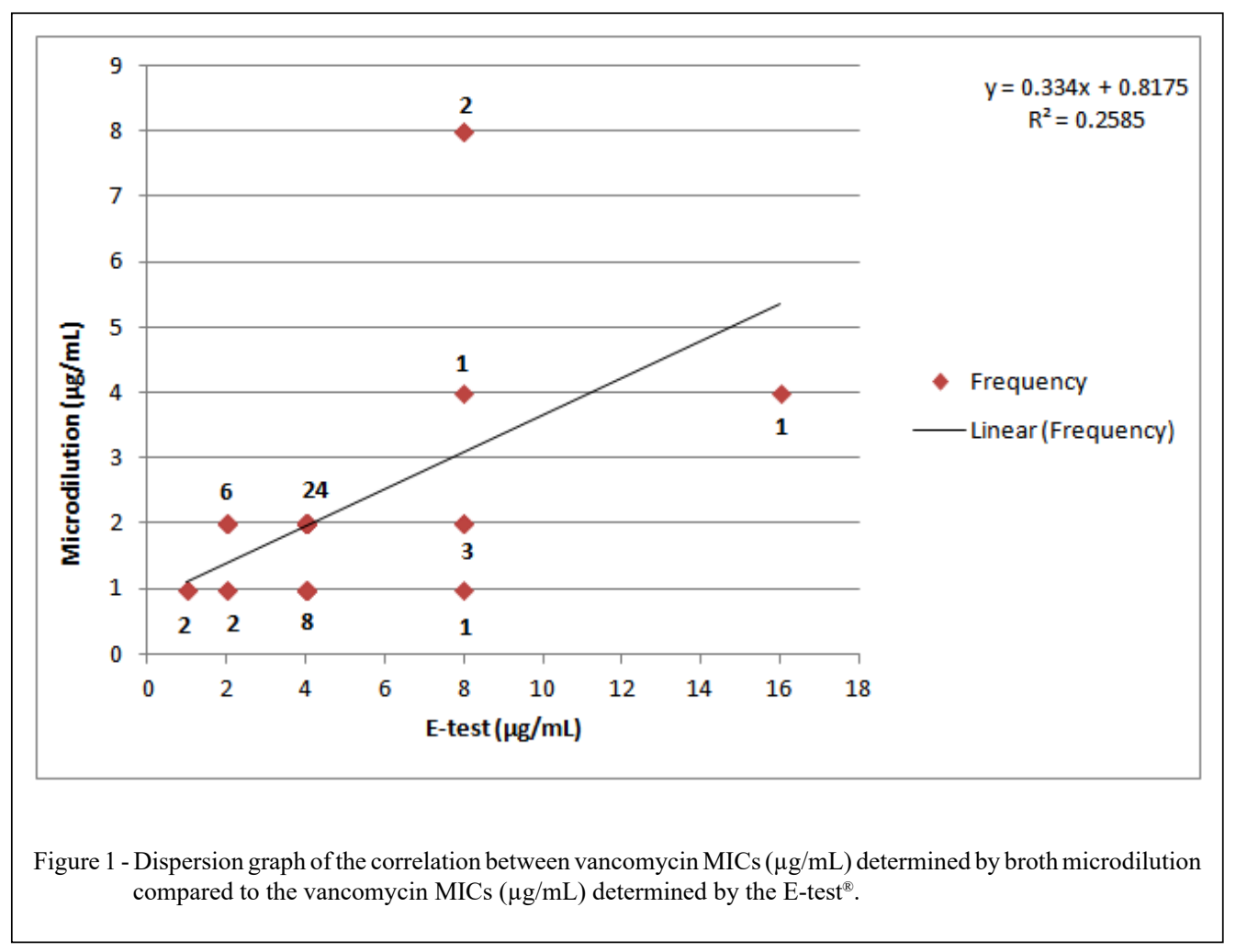

Ciência Rural, v.50, n.7, 2020. 
constitute a risk factor associated with an elevated MIC of vancomycin (GOMES et al., 2015).

The significant increase in methicillinresistant Staphylococcus spp. in recent years represents a risk not only for animals, but also for humans, since pet animals can participate in the crosstransmission of these multi-resistant isolates within the family environment (MORRIS et al., 2012). Allied to this, it has been reported that vancomycin shows low performance against Staphylococcus spp. resistant to methicillin that exhibit MICs close to the limit of susceptibility, demonstrating therapeutic failure (HUANG et al., 2016).

According to ROSSATO et al. (2014), the apparent increase in vancomycin MIC values between isolates of Staphylococcus spp. observed in recent years may represent the first step towards the occurrence of resistant isolates. In fact, the appearance of these strains, which are associated with therapeutic failure, was determined by the presentation of intermediate resistance or heteroresistance. Another factor responsible for the increase in MIC values of this antimicrobial is the use of vancomycin analogues such as avoparcin, which is used extensively as a growth enhancer in farm animals (WIJESEKARA et al., 2017).

In the present study, the isolates showed high susceptibility to vancomycin through the two tests used, which may be due to the low use of this antimicrobial in companion animals (SILVA et al., 2014). In a study of antimicrobial resistance in $S$. pseudintermedius isolated from dogs, RUZAUSKAS et al. (2016) observed that the isolates were only susceptible to antimicrobials of atypical use in veterinary medicine (vancomycin, linezolid and daptomycin), emphasising that such antimicrobials can only be used in the treatment of infections in humans to prevent the spread of resistance.

The detection of isolates with intermediate resistance varied according to the tests. The E-test ${ }^{\circledR}$ detected the largest number of isolates (n $=7)$ compared to the microdilution $(\mathrm{n}=3)$, with

Table 2 - Distribution of minimum inhibitory concentration (MIC) values for vancomycin obtained by broth microdilution and E-test ${ }^{\circledR}$ methods according to the Staphylococcus species isolated from animals.

\begin{tabular}{|c|c|c|c|c|c|}
\hline \multirow[t]{2}{*}{ Species } & \multicolumn{5}{|c|}{ - } \\
\hline & 1 & 2 & 4 & 8 & 16 \\
\hline \multicolumn{6}{|c|}{ 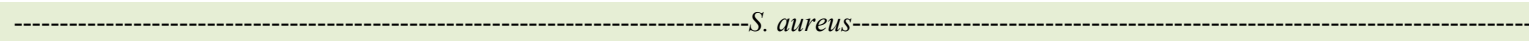 } \\
\hline Microdilution & 0 & 1 & 1 & 0 & 0 \\
\hline E-test & 0 & 0 & 1 & 1 & 0 \\
\hline \multicolumn{6}{|c|}{ - } \\
\hline Microdilution & 0 & 2 & 0 & 0 & 0 \\
\hline E-test & 0 & 0 & 2 & 0 & 0 \\
\hline \multicolumn{6}{|c|}{------1 } \\
\hline Microdilution & 0 & 2 & 0 & 0 & 0 \\
\hline E-test & 0 & 2 & 0 & 0 & 0 \\
\hline \multicolumn{6}{|c|}{ 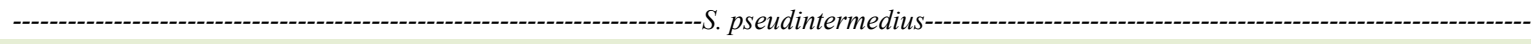 } \\
\hline Microdilution & 12 & 18 & 0 & 2 & 0 \\
\hline E-test & 2 & 3 & 22 & 4 & 1 \\
\hline \multicolumn{6}{|c|}{ 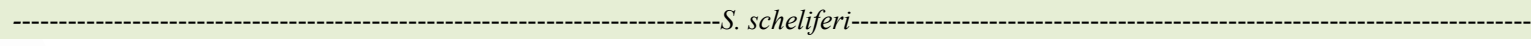 } \\
\hline Microdilution & 0 & 9 & 0 & 1 & 0 \\
\hline E-test & 0 & 0 & 7 & 1 & 0 \\
\hline \multicolumn{6}{|c|}{ 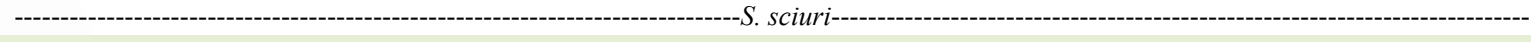 } \\
\hline Microdilution & 0 & 1 & 0 & 0 & 0 \\
\hline E-test & 0 & 0 & 1 & 0 & 0 \\
\hline \multicolumn{6}{|c|}{ - } \\
\hline Microdilution & 1 & 0 & 0 & 0 & 0 \\
\hline E-test & 0 & 1 & 0 & 0 & 0 \\
\hline \multicolumn{6}{|c|}{ 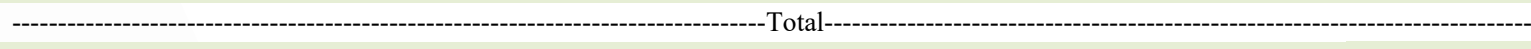 } \\
\hline Microdilution & 13 & 33 & 1 & 3 & 0 \\
\hline E-test & 2 & 8 & 33 & 6 & 1 \\
\hline
\end{tabular}


three of the isolates being identified in both tests. This is probably due to the differences in the MIC detection of this antimicrobial by these techniques. Although, the E-test ${ }^{\circledR}$ is very effective in determining the vancomycin MIC, it is advisable that broth dilution methodologies are also used for strains with MICs close to the susceptibility cut-off point (MANFREDINI et al., 2011) since the E-test ${ }^{\mathbb{B}}$ tends to provide higher MIC results of vancomycin than microdilution in broth, resulting in a greater number of intermediate isolates (SWENSSON et al., 2009; PAIVA et al., 2010; MANFREDINI et al., 2011).

MORENO et al. (2016) reported the first methicillin-resistant $S$. aureus vancomycinintermediate associated with livestock in Brazil (LA-MRSA ST398 / t9538), isolated from pigs with exudative epidermitis. The ST398 clone has been associated with livestock, especially pig farming, but it has also been linked to infections in humans, including patients with cystic fibrosis (LIMA et al., 2017). The identification of this MDR isolate warns of the high risk to public health and highlighted the need for further studies and surveillance actions on these microorganisms.

Companion and production animals are constantly implicated as potential reservoirs of Staphylococcus spp. with reduced sensitivity to antimicrobials, representing a potential risk to public health. Infections in humans by these microorganisms have already been reported, mainly by $S$. pseudintermedius, which is not part of the human microbiota and is believed to have a zoonotic character (PRIYANTHA et al., 2016, LOZANO et al., 2017, KMIECIAK \& SZEWCZYK, 2018).

Thus, control measures with a "One Health" approach must be taken, including the prudent and correct use of antimicrobials in veterinary medicine to preserve the effectiveness of drugs for both animal and human use, as well as surveillance actions to decrease the number of MDR bacteria (CERIC et al., 2019).

Statistically significant associations ( $\mathrm{P}<0.05)$ were observed between the isolated Staphylococcus spp. (S. pseudintermedius) and the host (canine), as well between the Staphylococcus spp. (S. pseudintermedius) and the isolation site (ear). These associations were possibly due to the greater amount of samples obtained from canine otitis.

Only four isolates had conflicting results in the two tests (intermediate in the E-test and sensitive in the microdilution in broth): $S$. pseudintermedius isolated from eye swab, dog ear and fur; and $S$. aureus isolated from bovine faeces. The Kappa test agreement obtained a value of 0.56 , which, according to LANDIS \& KOCH (1977), gives a substantial agreement between them.

In conclusion, this is the first study on the susceptibility profile of Staphylococcus spp. isolated from domestic and wild animals to vancomycin in Mato Grosso, Brazil. Our results revealed an increase in the MIC values of vancomycin by broth microdilution and E-test ${ }^{\circledR}$ techniques, with the presence of seven Staphylococcus spp. isolates being detected with intermediate resistance to vancomycin. This is aggravated by the fact that $78 \%$ of the tested isolates have the mecA gene, thus representing a potential risk to public health and the spread of these microorganisms.

\section{ACKNOWLEDGMENTS}

We thank Coordenação de Aperfeiçoamento de Pessoal de Nível Superior (CAPES) for the financial support.

\section{DECLARATION OF CONFLICT OF INTERESTS}

The authors declare that there are no potential conflicts of interest regarding the research, authorship and/or publication of this article.

\section{AUTHORS' CONTRIBUTIONS}

The authors contributed equally to the manuscript.

\section{REFERENCES}

BAUER, A. W. et al. Antibiotic susceptibility testing by a standardized single disk method. American Journal of Clinical Pathology. v.45, n.4, p.493-496, 1966. Available from: <https:// academic.oup.com/ajcp/article-abstract/45/4 ts/493/4821085?re directedFrom=fulltext $>$. Accessed: Nov 05, 2016. doi: 10.1093/ ajcp/45.4_ts.493.

CAMPANA, E. H. et al. Evaluation of M.I.C.E.TM, Etest ${ }^{\circledR}$ and CLSI broth microdilution methods for antimicrobial susceptibility testing of nosocomial bacterial isolates. Jornal Brasileiro de Patologia e Medicina Laboratorial. v.47, n.2, p.157-164, 2011. Available from: <http://www.scielo.br/pdf/jbpml/v47n2/ v47n2a11.pdf $>$. Accessed: Feb. 03, 2017. doi: 10.1590/S167624442011000200011.

CERIC, O. et al. Enhancing the one health initiative by using whole genome sequencing to monitor antimicrobial resistance of animal pathogens: Vet-LIRN collaborative project with veterinary diagnostic laboratories in United States and Canada. BMC Veterinary Research. v.15, n.130, p.1-13, 2019. Available from: <https://bmcvetres. biomedcentral.com/articles/10.1186/s12917-019-1864-2>. Accessed: Jun. 29, 2019. doi: 10.1186/s12917-019-1864-2.

CHOI, S. M. et al. Multiplex PCR for the detection of genes encoding aminoglycoside modifying enzymes and methicillin resistance among Staphylococcus species. Journal of Korean 
Medical Science, v.18, n.5, p.631-6, 2003. Available from: $<\mathrm{http}: / /$ www.ncbi.nlm.nih.gov/pubmed/14555812>. Accessed: Feb. 02, 2017. doi: $10.3346 / \mathrm{jkms} .2003 .18 .5 .631$

CLSI. Performance Standards for Antimicrobial Disk and Dilution Susceptibilit Tests for Bacteria Isolated from Animals; Second Informational Supplement. Wayne, PA: Clinical and Laboratory Standards Institute, 2013. (CLSI document VET01-S2)

GODOY, I. et al. Antimicrobial susceptibility profiles of Staphylococcus spp. from domestic and wild animals. Ciência Rural. v.46, n.12, p.2148-2151, 2016. Available from: <http://www.scielo.br/ scielo.php?script=sci_arttext\&pid=S0103-84782016001202148>. Accessed: Apr. 25, 2017. doi: 10.1590/0103-8478cr20160373.

GOMES , D. M. et al. Clinical implications of vancomycin heteroresistant and intermediately susceptible Staphylococcus aureus. Pharmacotherapy: The Journal of Human Pharmacology and Drug Therapy. v.35, n.4, p.424-432, 2015. Available from: $<$ https://accpjournals.onlinelibrary.wiley.com/doi/abs/10.1002/ phar.1577>. Accessed: Jan. 29, 2019. doi: 10.1002/phar.1577.

HIRAMATSU, K. et al. Methicillin-resistant Staphylococcus aureus clinical strain with reduced vancomycin susceptibility. Journal of Antimicrobial Chemotherapy. v.40, n.1, p.135136, 1997. Available from: <https://academic.oup.com/jac/article/40/1/135/816631>. Accessed: Mar. 16, 2017. doi: 10.1093/ jac/40.1.135.

HUANG, S. H. et al. Prevalence of vancomycin-intermediate Staphylococcus aureus (VISA) and heterogeneous VISA among methicillin resistant $S$. aureus with high vancomycin minimal inhibitory concentrations in Taiwan: A multicenter surveillance study, 20122013. Journal of Microbiology, Immunology and Infection. v.49, n.5, p.701-707, 2016. Available from: <https://www.sciencedirect. com/science/article/pii/S1684118215008063?via\%3Dihub>. Accessed: Feb. 03, 2017. doi: 10.1016/j.jmii.2015.07.003.

KMIECIAK, W.; SZEWCZYK, E. M. Are zoonotic Staphylococcus pseudintermedius strains a growing threat for humans? Folia Microbiologica. v.63, n.6, p.743-747, 2018. Available from: $<$ https:// link.springer.com/article/10.1007\%2Fs12223-018-0615-2>. Accessed: Jul. 29, 2019. doi: 10.1007/s12223-018-0615-2.

LANDIS, J. R.; KOCH, G. G. The measurement of observer agreement for categorical data. Biometrics. v.33, n.1, p.159-174, 1977. Available from: $<$ https://www.ncbi.nlm.nih.gov/pubmed/843571>. Accessed: Oct. 25, 2018. doi: PMID: 843571.

LIMA, D. F. et al. Genomic information on multidrug-resistant livestock-associated methicillin-resistant Staphylococcus aureus ST398 isolated from a Brazilian patient with cystic fibrosis. Memórias do Instituto Oswaldo Cruz. v.112, n.1, p.79-80, 2017 Available from: <http://www.scielo.br/scielo.php?script=sci_arttext\&pid=S0074=02762017000100079-\&lng=en\&nrm=iso\&tingen>. Accessed: Aug. 13, 2019. doi: 10.1590/0074-02760160342.

LOUREIRO, R. J. et al. Use of antibiotics and bacterial resistances: Brief notes on its evolution. Revista portuguesa de Saúde pública. v.34, n.1, p.77-84, 2016. Available from: $<$ https://www. sciencedirect.com/science/article/pii/S087090251500067X $>$. Accessed: Aug. 28, 2018. doi: 10.1016/j.rpsp.2015.11.003.

LOZANO C. et al. Staphylococcus pseudintermedius human infection cases in Spain: dog-to-human transmission. Vector
Borne Zoonotic Diseases. v.17, n.4, p.268-270, 2017. Available from: <https://www.liebertpub.com/doi/abs/10.1089/ vbz.2016.2048?rfr_dat=cr_pub\%3Dpubmed\&url_ver=Z39.88$2003 \&$ rfr id $=$ ori $\% 3$ Arid $\% 3$ Acrossref.org \& journalCode $=v b z>$. Accessed: Jul. 26, 2019. doi: 10.1089/vbz.2016.2048.

MANFREDINI, C. et al. Comparison of methods to determination of vancomycin sensivity in methicillin-resistant Staphylococcus aureus. Jornal Brasileiro de Patologia e Medicina Laboratorial. v.47, n.2, p.141-145, 2011. Available from: <http://www.scielo.br/pdf/jbpml/v47n2/ v47n2a08.pdf $>$. Accessed: Feb. 03, 2017. doi: 10.1590/ S1676-24442011000200008.

MCGUINNESS, W. A. et al. Vancomycin Resistance in Staphylococcus aureus. Yale Journal of Biology and Medicine. v.90, n.2, p.269-281, 2017. Available from: $<$ https://www.ncbi.nlm.nih. gov/pmc/articles/PMC5482303/>. Accessed: Jul. 28, 2019. doi: PMC5482303.

MORENO, L. Z. et al. Vancomycin-intermediate livestock-associated methicillin-resistant Staphylococcus aureus ST398/t9538 from swine in Brazil. Memórias Instituto Oswaldo Cruz. v.111, n.10, p.659-661, 2016. Available from: <http://www.scielo.br/ pdf/mioc/v111n10/0074-0276-mioc-111-10-0659.pdf >. Accessed: Feb. 02, 2017. doi: 10.1590/0074-02760160276.

MORRIS, D. O. et al. Potential for pet animals to harbour methicillin-resistant Staphylococcus aureus when residing with human MRSA patients. Zoonoses Public Health, v.59, n.4, p.286-93, 2012. Available from: <https://www.ncbi.nlm.nih.gov/ pubmed/22233337>. Accessed: Oct. 23, 2016. doi: 10.1111/j.18632378.2011.01448.x

ORGANIZAÇÃO DAS NAÇÕES UNIDAS BRASIL. Relatório para o Secretário Geral das Nações Unidas, abril de 2019. Resumo das recomendações e mensagens-chave. Interagency Coordination Group on Antimicrobial Resistance (IACG). Available from: <https://www.who.int/antimicrobial-resistance/ interagency-coordination-group/IACG_final_summary_ PT.pdf?ua=1>. Accessed: Aug. 12, 2019.

PAIVA, R. M. et al. Vancomycin MIC for Methicillin-Resistant Coagulase-Negative Staphylococcus Isolates: Evaluation of the Broth Microdilution and Etest Methods. Journal of Clinical of Microbiology. v.48, n.12, p.4652-4654, 2010. Available from: $<$ https://jcm.asm.org/content/48/12/4652.long>. Accessed: Mar. 15, 2018. doi: 10.1128/JCM.01182-10.

PAPICH M. G. Antibiotic treatment of resistant infections in small animals. Veterinary Clinics of North America: Small Animal Practice. v.43, n.5, p.1091-1107, 2013. Available from: <https://www.sciencedirect.com/science/article/pii/ S0195561613001113?via\%3Dihub>. Accessed: Mar. 13, 2017. doi: 1016/j.cvsm.2013.04.006.

PRIYANTHA, R. et al. Antimicrobial susceptibility of Staphylococcus pseudintermedius colonizing healthy dogs in Saskatoon, Canada. The Canadian Veterinary Journal. v.57, n.1, p.65-69, 2016. Available from: <https://www.ncbi.nlm.nih. gov/pmc/articles/PMC4677612/>. Accessed: Jul. 28, 2018. doi: PMC4677612.

ROSSATTO, F. C. P. et al. Evaluation of methods in detecting vancomycin MIC among MRSA isolates and the changes in accuracy related to different MIC values. 
Revista do Instituto de Medicina Tropical de São Paulo São Paulo, v.56, n.6, p.469-472, 2014. Available from: $<$ http://www.scielo.br/scielo.php?script=sci_arttext\&pid =S0036-46652014000600469>. Accessed: Apr. 24, 2017. doi: $10.1590 / \mathrm{s} 0036-46652014000600002$.

RUZAUSKAS, M. et al. Characterization of Staphylococcus pseudintermedius isolated from diseased dogs in Lithuania. Polish Journal of Veterinary Sciences. v.19, n.1, p.7-14, 2016. Available from: <http://journals.pan.pl/dlibra/publication/114403/ edition/99456/content>. Accessed: May, 15, 2017. doi: 10.1515/ pjvs-2016-0002.

SAPUTRA, S. et al. Antimicrobial resistance in coagulase-positive staphylococci isolated from companion animals in Australia: A one year study. PLoS ONE v.12, n.4, p.1-17, 2017. Available from: $<$ https://journals.plos.org/plosone/article?id=10.1371/journal. pone.0176379>. Accessed: May, 15, 2017. doi: 10.1371/journal. pone. 0176379 .
SILVA, A. P. et al. Suscetibilidade antimicrobiana de Staphylococcus spp. isolados de cães com pioderma superficial. Pesquisa Veterinária Brasileira. v.34 n.4, p.355-361, 2014. Available from: $<$ http://www.scielo.br/pdf/pvb/v34n4/10.pdf > . Accessed: Feb. 03, 2017. doi: 10.1590/S0100-736X2014000400010.

SWENSON, J. M. et al. Accuracy of commercial and reference susceptibility testing methods for detecting VancomycinIntermediate Staphylococcus aureus. Journal of Clinical Microbiology. v.47, n.7, p.2013-2017, 2009. Available from: $<$ https://jcm.asm.org/content/47/7/2013.long>. Accessed: Aug. 12, 2019. doi: 10.1128/JCM.00221-09.

WIJESEKARA, P. N. K. et al . Review on usage of vancomycin in livestock and humans: maintaining its efficacy, prevention of resistance and alternative therapy. Veterinary Sciences. v.4, n.1, p.1-11, 2017. Available from: <https://www.ncbi.nlm.nih. gov/pmc/articles/PMC5606620/>. Accessed: Jul. 30, 2019. doi: 10.3390/vetsci4010006. 